\title{
Ikerpárban előforduló örökletes phaeochromocytoma
}

\author{
Tóth Géza dr. ${ }^{1}$ - Patócs Attila dr. ${ }^{2}$ - Tóth Miklós dr. ${ }^{3}$ \\ 'Szent Lázár Megyei Kórház, Endokrinológiai szakrendelés, Salgótarján \\ ${ }^{2}$ Magyar Tudományos Akadémia-Semmelweis Egyetem, \\ Lendület Örökletes Endokrin Daganatok Kutatócsoport, Budapest \\ ${ }^{3}$ Semmelweis Egyetem, Általános Orvostudományi Kar, II. Belgyógyászati Klinika, Budapest
}

\begin{abstract}
A phaeochromocytoma a katecholamin-termelő mellékvesevelő neuroendokrin sejtjeinek daganata. Az extraadrenalisan elhelyezkedő phaeochromocytomákat paragangliomának nevezzük. A phaeochromocytomák nagy része sporadikusan fordul elő, de mintegy 25-30\%-uk genetikai eredetü, örökletes forma. Az örökletes phaeochromocytomaparaganglioma szindrómák incidenciája folyamatosan növekszik. Ez egyrészt az egyre szélesebb körben elterjedő genetikai vizsgálatokkal, valamint az újabb gének felfedezésével függ össze. A középkorú nőbetegnél végzett komputertomográfia során derült fény kétoldali mellékvese-nagyobbodásra. A kiegészítő képalkotó vizsgálatok, a vizeletkatecholamin- és szérum-chromogranin-A-eredmények kétoldali phaeochromocytoma jelenlétét erősítették meg. A beteg egypetéjú ikertestvérénél is hasonló, hormonálisan aktív kétoldali phaeochromocytoma igazolódott, ezért felmerült öröklődő, familiáris phaeochromocytoma lehetősége. Ennek igazolására genetikai vizsgálat történt, ami a nemrégiben felismert transzmembrán protein 127 tumorszuppresszor gén mutációját igazolta. A kivizsgálást követően mindkét betegnél mellékvese-megtartó műtétre került sor, amely során a nagyobb daganatot tartalmazó mellékvesét teljes egészében reszekálták, míg az ellenkező oldalon a mellékvese velőállományát eltávolítva mellékvesekéregállományt hagytak vissza. A mútétet követően mindkét betegnél a vizeletkatecholamin-és szérum-chromograninA-szintek normalizálódtak. A mellékvesekéreg-megtartó műtét ellenére az egyik betegnél mellékvesekéreg-elégtelenség alakult ki, ami miatt tartós glükokortikoidpótlásra szorul. Az eset különlegességét az adja, hogy az áttekintett irodalomban és a rendelkezésre álló nemzetközi phaeochromocytoma-regiszterekben sem egypetéjű, sem kétpetéjű ikerpárról a szerzők nem találtak említést. Az egész családra kiterjesztett genetikai vizsgálat során 4 generáción keresztül sikerült igazolni a mutáns gén jelenlétét. Orv. Hetil., 2016, 157(33), 1326-1330.
\end{abstract}

Kulcsszavak: örökletes phaeochromocytoma, TMEM127 génmutáció, egypetéjü ikrek

\section{Hereditary phaeochromocytoma in twins}

Phaeochromocytoma is a tumor of the catecholamine-producing cells of the adrenal gland. Extraadrenal phaeochromocytomas are frequently called paragangliomas. The majority of phaeochromocytomas are sporadic, however, about $25-30 \%$ are caused by genetic mutation. These tumor are frequently referred as hereditary phaeochromocytomas/ paragangliomas. Their incidence increases continuously which can be attributed to availability of genetic examination and to the discovery of novel genes. The 47-year-old female patient underwent abdominal computed tomography which revealed bilateral adrenal gland enlargement. Abdominal magnetic resonance imaging, the 131-I- metaiodobenzylguanidine scintigraphy, urinary catecholamines and serum chomogranin A measurements confirmed the diagnosis of bilateral phaeochromocytomas. The genetically identical twin sister of the patient was also diagnosed with hormonally active bilateral phaechromocytoma, suggesting the genetic origin of phaeochromocytoma. Mutation screening confirmed a germline mutation of the transmembrane protein 127 tumorsupressor gene in both patients. Both patients underwent cortical-sparing adrenalectomy. The adrenal gland with the larger tumor was totally resected, while in the opposite side only the tumor was resected and a small part of the cortex was saved. After the operation urinary catecholamines and serum chromogranin A returned to normal in both patients. Adrenocortical deficiency was absent in the first patient, but her sister developed adrenal insufficiency requiring glucocorticoid replacement. To the best of the authors' knowledge phaeochromocytoma affecting twins has never been described earlier. Genetic examination performed in siblings confirmed the presence of the mutant gene through four generations.

Keywords: hereditary phaeochromocytoma, TMEM127 gene mutation, identical twins

Tóth, G., Patócs, A., Tóth, M. [Hereditary phaeochromocytoma in twins]. Orv. Hetil., 2016, 157(33), 1326-1330.

(Beérkezett: 2016. április 27.; elfogadva: 2016. június 2.) 


\section{Rövidítések}

5-HIAA = 5-hidroxi-indolecetsav; $\mathrm{CgA}=$ chromogranin-A; $\mathrm{CT}=$ komputertomográfia; $\mathrm{DNS}=$ dezoxiribonukleinsav; HIFl-alfa = hypoxia indukálta faktor 1 -es típusa; HVA = homovanillinsav; ${ }^{131} \mathrm{I}-\mathrm{MIBG}=\mathrm{J}$-131-metajódbenzilguanidin; MEN = multiplex endokrin neoplasia; $\mathrm{MR}=$ mágneses rezonancia $; \mathrm{NFl}=$ neurofibromatosis 1 -es típusa $; \mathrm{PCR}=$ polimeráz láncreakció; $\mathrm{SDH}$ = szukcinát-dehidrogenáz; TMEM127 = transzmembrán protein 127; VHL = von Hippel-Lindauszindróma; $\mathrm{VMA}=$ vanillin-mandulasav

A phaeochromocytoma a mellékvesevelő neuroendokrin sejtjeinek katecholamin-termelő daganata. Ritka daganat, incidenciája 0,3-0,8/1 $000000 /$ év. Az összes hypertoniás eset mintegy $0,1-0,6 \%$-ának hátterében áll phaeochromocytoma. A véletlenül felfedezett mellékvese-daganatok, úgynevezett incidentalomák körülbelül 5-8\%-a phaeochromocytoma. Bármely életkorban elöfordulhat, de leggyakrabban az élet negyedik és ötödik évtizedében jelentkezik. Az esetek 20-25\%-ában kétoldali lokalizációjú, de gyermekkorban 30-35\%-ban fordul elő mindkét mellékvesében. Az extraadrenalis lokalizációjú phaeochromocytomákat paragangliomának hívjuk. $\mathrm{Az}$ összes phaeochromocytoma-eset 15-20\%-a paraganglioma, amelynek előfordulása gyermekekben gyakoribb. A paragangliomák mintegy $85 \%$-a a hasüregben található, elsősorban a juxtarenalis és paraaorticus régióban. A phaeochromocytomák 10-15\%-a, míg a paragangliomák 30-50\%-a malignus [1-4]. Jellegzetes eltérés észlelhető a hormontermelésben is. Míg a phaeochromocytomák általában adrenalint termelnek, addig a paragangliomák fóleg noradrenalint szekretálnak [2]. Az utóbbi évtizedekben a legszembeötlőbb változás a phaeochromocytomák megjelenésével kapcsolatban az örökletes formák gyakoriságának növekedése. Az ezredforduló óta több új génmutáció került felismerésre, amely phaeochromocytomát eredményez. Ezek az új genetikai eltérések oda vezettek, hogy a korábban sporadikusnak vélt phaeochromocytomák körülbelül 25-30\%áról kiderült, hogy azok genetikailag determinált, örökletes formák. E felismerés a családszűrés szempontjából fontos. Ahogy egyre bővül az ismert mutációk száma, úgy növekszik az öröklődő phaeochromocytomaformák aránya is.

\section{Esetismertetés}

A 47 éves nőbeteg anamnézisében krónikus betegség, kórházi kezelés, rendszeres gyógyszerszedés nem szerepelt. Bizonytalan hasi diszkomfort érzés miatt történt hasi CT-vizsgálat során észleltek a jobb oldali mellékvesében $16 \mathrm{~mm}$ átmérôjü, a bal mellékvesében $30 \mathrm{~mm}$ nagyságú, inhomogén kontrasztanyag-halmozást mutató térfoglaló képletet (1. ábra). A T2-súlyozott MR-felvételeken mindkét mellékvese-terime fokozott jelintenzitást mutatott (2. ábra). Ezek a képalkotó vizsgálatok

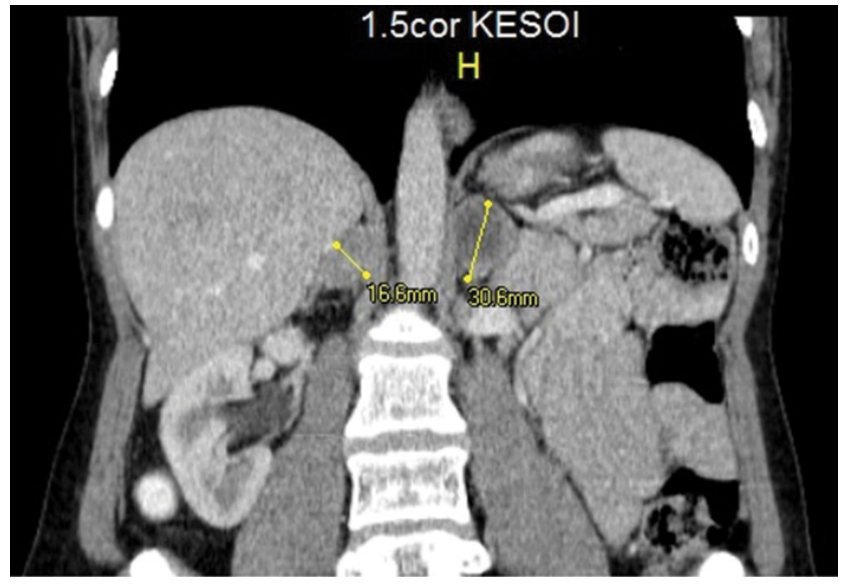

1. ábra $\quad$ Kontrasztos CT-n jobb oldali mellékvesében $16 \mathrm{~mm}$ átmérőjű, a bal mellékvesében $30 \mathrm{~mm}$ nagyságú, inhomogén kontrasztanyag-halmozást mutató térfoglaló képlet

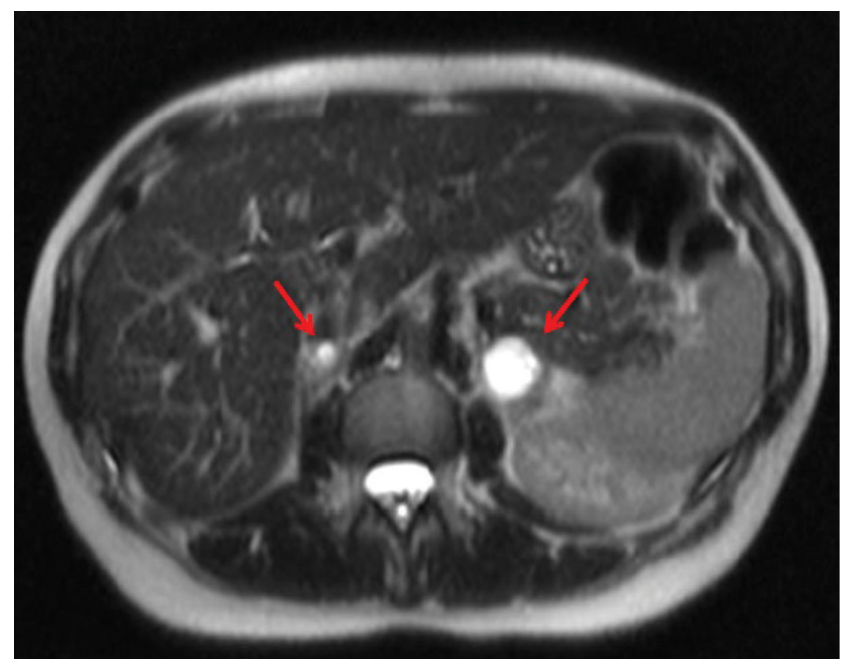

2. ábra

T2-súlyozott MR-felvételeken mindkét mellékvese-elváltozás fokozott jelintenzitást mutat

felvetették kétoldali phaeochromocytoma lehetőségét. A beteg semmi ezzel összefüggésbe hozható panaszt nem említett, mindig normotensiós volt. Rákérdezésre viszont már régóta voltak enyhe palpitatiós érzései, hőhullámai, végtagremegései, fejájásai, de ezeket a tüneteket elbagatellizálta, esetleges perimenopausának gondolta. Ezt követően J-131-metajódbenzilguanidin $\left({ }^{131}\right.$ I-MIBG) egésztest-szcintigráfia történt, amely során mindkét mellékvese-elváltozás akkumulálta a radiofarmakont (3. ábra). A hormonvizsgálatok kizárták a hypophysis- és mellékvesekéreg-diszfunkciót. A 24 órán át gyüjtött vizelet katecholamin-vizsgálata kifejezetten magas adrenalin- $(42,8 \mathrm{ug} / 24 \mathrm{~h}$; normális: 1,7-22,4 $\mathrm{ug} / 24 \mathrm{~h}$ ) és metanephrin- (1868 ug/24 h; normális: 64-302 ug/24 h) értéket mutatott. A dopamin-, noradrenalin-, normetanephrin-, vanillin-mandulasav (VMA), homovanillinsav- (HVA) és 5-hidroxi-indolecetsav- (5HIAA) értékek normális tartományban voltak. A chromogranin-A ( $\mathrm{CgA})$ vérszintje is a vártnak megfelelően 


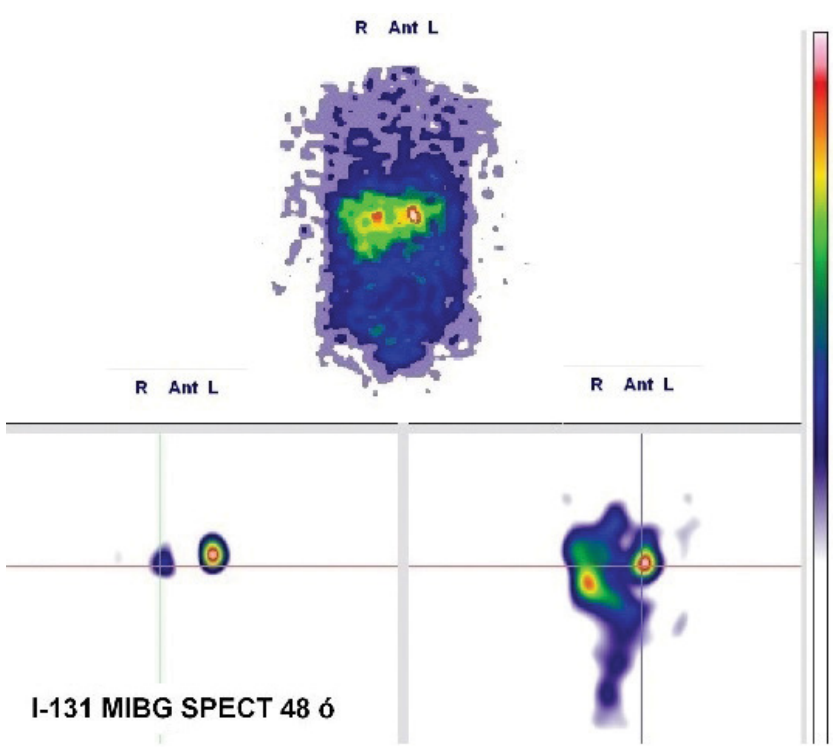

3. ábra $\mid{ }^{131} \mathrm{I}-\mathrm{MIBG}$ egésztest-szcintigráfián mindkét mellékvesében fokozott radiofarmakon-felvétel

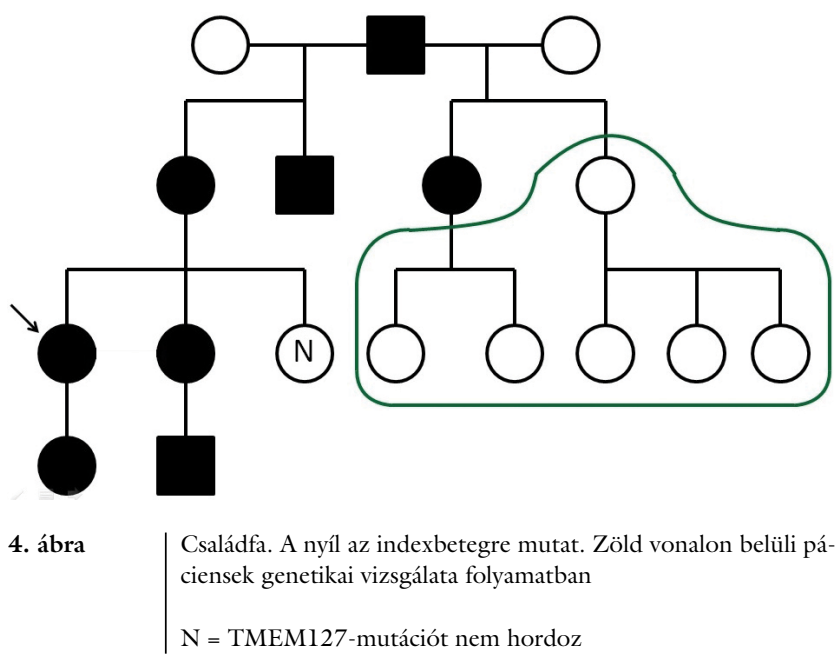

magas volt $(223,3 \mathrm{ng} / \mathrm{ml}$; normális: 19,4-98,1 ng/ml). Mindezen eredmények a kétoldali phaeochromocytoma tényét alátámasztották.

Ezt követôen genetikai szürésre került sor, amelynek során a RET, VHL, SDHB, SDHD és TMEMI27 gén vizsgálatát elvégezték. Adrenalis phaeochromocytoma esetén ezeknek a géneknek a vizsgálata javasolt első körben. Ennek eredményeképp a TMEM127 génben igazoltak egy kereteltolódást okozó mutációt (c.572delC). A TMEM127 gén egy transzmembrán fehérjét kódol, funkcióját tekintve tumorszuppresszor hatású. Tekintettel a beteg fiatal korára, mellékvese-kímélő mútétre került sor, vagyis a nagy bal oldali mellékvesét egészében reszekálták, de a kisebb jobb oldali mellékvesét csak részlegesen távolították el, azaz kis mellékvesekéreg-állományt visszahagytak a teljes velőállomány exstirpálása mellett. A szövettan mindkét mellékvese-daganat esetében phaeochromocytomát igazolt.
A mütétet követően a beteg vizeletadrenalin és -metanephrin-ürítése, valamint a szérum CgA-szintje normalizálódott. Hypadrenia nem alakult ki. A korábbi palpitatioérzés, izzadás, remegés megszűnt.

A beteg kivizsgálása közben derült ki, hogy van egy egypetéjú ikertestvére. A testvérnek sincs krónikus betegsége, rendszeresen gyógyszert nem szedett. A részletes anamnézis sem derített fényt panaszokra vagy tünetekre. Az első lépésben elvégzett tájékozódó jellegú hasi CT során az indexbeteggel teljesen megegyezően jobboldalt $15 \mathrm{~mm}$-es, baloldalt $30 \mathrm{~mm}$-es mellékvese-terimét írtak le. Az MR és az ${ }^{131}$ I-MIBG szcintigráfia is az ikertestvéréhez hasonlóan pozitív eredményt adott. A szérum CgA-szintje felső tartományban volt $(88,6 \mathrm{ng} /$ $\mathrm{ml})$, a vizeletadrenalin $(24,5 \mathrm{ug} / 24 \mathrm{~h})$ és -metanephrin $(976 \mathrm{ug} / 24 \mathrm{~h})$ ürítése magasabb volt. Mindezen eredmények kétoldali phaeochromocytoma tényét támasztották alá, és a genetikai vizsgálat kimutatta a testvérében azonosított TMEM127 gén mutációját. Ezt követően ikertestvéréhez hasonlóan mellékvese-kímélő mútétre került sor. A szövettan itt is igazolta mindkét mellékvesevelőben a phaeochromocytoma meglétét. A mû́tét után, sajnos, hypadrenia alakult ki, amely miatt glükokortikoidszubsztitúcióra szorult. Mineralokortikoidpótlásra nem volt szükség. A phaeochromocytoma eltávolítása után a vizeletben az adrenalin és metanephrin ürítése normalizálódott.

Az ikerpár családtagjainál családszűrést végeztünk, amely jelenleg is folyamatban van. A kimutatott TMEM127 gén mutációjának jelenlétét négy generáción keresztül tudtuk igazolni (4. ábra).

\section{Megbeszélés}

A molekuláris genetikai módszerek fejlődésének és egyre szélesebb körben történő elterjedésének köszönhetően a sporadikusan felismert phaeochromocytomák közel 25\%-ában találhatunk csírasejt-mutációkat. Ezek egy része a szülő́ktől örökölt eltérés, más részük sporadikusan keletkező, úgynevezett de novo mutáció. Örökletes phaeochromocytoma 4 familiáris daganatszindrómában fordul elő. Ezek a multiplex endokrin neoplasia 2 -es típusa (MEN2), a von Hippel-Lindau-szindróma (VHL), a neurofibromatosis l-es típusa (NFl) és a 2000-es években felismert öröklődő familiáris paraganglioma/ phaeochromocytoma szindrómák [1, 4-7]. Ezek mellett az elmúlt 5-6 évben számos genetikai eltérést, mutációt igazoltak, amelyek phaeochromocytomát, esetleg paragangliomát eredményeznek, de nem köthetők daganatszindrómához.

A MEN2-szindróma kialakulásáért a Ret protoonkogén, a VHL-szindrómáért a Vhl tumorszuppresszor gén, az NFl-ért a neurofibromin gén mutációi felelősek. A familiáris paraganglioma/phaeochromocytoma szindrómák hátterében a mitochondrialis légzési lánc egyik enzimjének, a szukcinát-dehidrogenáz (SDH) alegységeit kódoló gének (SDHAF2, SDHB, SDHC, SDHD) 
mutációit mutatták ki. A legújabban felismert phaeochromocytomát eredményező genetikai mutációkat 2008-ban KIFlB-béta és EGLN1 (ismert PHD2 néven is), 2010-ben TMEM127 és 2011-ben MAX génekben találták [2, 4, 5, 7-9]. A funkcionális genomikai vizsgálatok eddigi eredményei alapján a phaeochromocytomák patogenezisüket tekintve alapvetően két csoportba oszthatók. A Vhl, SDH és EGLNl gének, valamint a Ret, NF1, MAX és TMEM127 gének mutációi talaján kialakult daganatok csoportjára. A Vhl, SDH és EGLNl gének mutációi elsősorban a hypoxia indukálta faktor l-es típusának (HIFl-alfa) fokozott expressziója révén okoznak daganatot. Ezen mutációk esetén a HIFl-alfa normális oxigénellátottság esetén is aktív marad, és angiogenetikus faktorok termelődésének elősegítésével serkentheti a daganat növekedését. A Ret és NFl gének mutációi elsősorban a Ras protoonkogénen, a MAX tumorszuppresszor gén mutációja a MYC/MAX/MXDl útvonalon, míg a TMEM127 gén mutációja az m-TOR rendszeren keresztül fokozzák a sejtproliferációt $[1,3$, 5-7, 10].

Betegeink esetében a TMEM127 gén mutációját találtuk. TMEM127-es gén a 2. kromoszóma hosszú karján, a 11.2-es locuson helyezkedik el (2q11.2). A gén 4 exonból áll $[8,11]$. Betegeinknél a 4 -es exon c.572-es pozíciójában mutattunk ki egy citozindeletióval járó mutációt. A gén által kódolt TMEM127 fehérje egy 238 aminosavból álló protein, amely 3 transzmembrán doménnel rendelkezik. Ezen keresztül szoros kapcsolatban van a korai endosomalis struktúrákkal, Golgi-apparátussal, lysosomákkal, és részt vesz ezen sejtalkotók közti fehérjetranszportban. A TMEM127 fehérje gátolja az mTOR, azon belül az m-TORCl-komplex múködését, ezáltal szabályozva a sejtproliferációt, sejtnövekedést, sejtmotilitást [3, 9, 12-14].

Mivel a mutáns gén jelenlétét nemcsak a betegeinkben és azok gyermekeiben mutattuk ki, hanem a szüleikben és a nagyszülőkben is, egyértelmü, hogy nem sporadikusan keletkező de novo, hanem öröklött mutációról van szó. Ezen gén mutációjának jelenlétét négy generáción keresztül tudtuk dokumentálni. Az áttekintett irodalomban és a rendelkezésre álló nemzetközi phaeochromocytoma-regiszterekben öröklődő phaeochromocytomában szenvedő ikerpárról nem találtunk említést. Az a tény, hogy az indexbeteg egypetéjü ikertestvére is hordozza a hibás gént, és benne is teljesen hasonló időben és morfológiailag megegyezően manifesztálódott a betegség, egyedülállónak számít.

Az is említésre méltó, hogy egyik betegnél sem dokumentáltunk manifeszt hypertoniát, holott a phaeochromocytomák 85-90\%-ában a legfontosabb klinikai tünet a magas vérnyomás. A sporadikus esetekben szinte mindig találkozunk magasabb vérnyomással, míg familiáris phaeochromocytomák esetén nem ritka a normális vérnyomás. A phaeochromocytomában előforduló hypertonia mértéke és egyéb tünetek jelenléte erősen korrelál a daganat által termelt katecholaminok mennyiségével
[15]. Az indexbeteg esetében a phaeochromocytoma jellegzetes triásza, azaz a fejfájás, palpitatio és izzadás jelen volt, amely tünetek a mútét után megszüntek. Ezzel függhet össze, hogy bár az indexbetegnél sem találtunk magas vérnyomást, de a magas adrenalin- és metanephrinürítésnek köszönhetően a jellegzetes triász kialakult. Ezzel szemben ikertestvérénél, akinek sem a $\mathrm{CgA}$, sem az ürített vizelet katecholaminok mennyisége nem volt kifejezett, még nem alakultak ki a phaeochromocytomára jellegzetes tünetek.

A phaeochromocytomával összefüggő génmutációk autoszomális domináns módon öröklődnek, így heterozigóta formában manifesztálódhat. Az utódoknak 50\% esélyük van a kóros gén öröklésére, amely a családszürés jelentőségét erősíti. Minden genetikai eltérésnek más a penetranciája, azaz a betegség manifesztálódásának a valószínúsége. Ebből következik, hogy a dominánsan továbbadódó genetikai malformáció nem feltétlenül vezet manifeszt klinikai betegséghez. Például az NFl gén mutációja esetén 0,1-5\%-ban fordul elő phaeochromocytoma, a VHL esetén ez az arány 10-26\%, míg a MEN2-szindrómás betegek felében alakul ki phaeochromocytoma. Az SDHAF2 gén mutációja minden esetben betegséghez, azon belül paragangliomához vezet. A többi SDH-alegységet kódoló gén mutációja 7786\%-ban vezet paraganglioma/phaeochromocytoma szindrómához $[3,4,5,7,9]$. Az újonnan felfedezett EGLN1, MAX, TMEM127 gének penetranciájáról még nincs pontos információ, mivel egyelőre kevés adat áll rendelkezésre. A saját esetünkben feltérképezett családban az egypetéjú ikerpáron kívül, a többi genetikailag érintett családtagban phaeochromocytomát nem tudtunk kimutatni.

Nemcsak a penetranciában, hanem a malignitásra való hajlamban is különbséget találunk az egyes genetikai mutációk okozta phaeochromocytomák esetében. Míg a sporadikus phaeochromocytomák 4-5\%-a malignus, addig az öröklött formák esetén széles határok közt változik a rosszindulatúságra való hajlam. A régebb óta ismert familiáris daganatszindrómákban (VHL, NF1, MEN2) 3-9\%-ban találunk malignus elfajulást, az SDHB gén mutációja során kialakult paraganglioma/phaeochromocytoma 4-es típusa (PGL4) egyharmada rosszindulatú. A MAX gén mutációja esetén a betegek negyedénél mutatható ki malignus phaeochromocytoma, míg a TMEM127 gén mutációja esetén csak a betegek közel 4\%-ánál $[3,4,10,16,17]$. A phaeochromocytomák esetén a malignitásról nehéz nyilatkozni, mivel mai ismereteink szerint nincs egyértelmű morfológiai, klinikai, patológiai, szövettani, immunhisztokémiai, genetikai jel vagy egyéb tényező, amely a malignitást jelezné. A malignitás kizárólagos bizonyítéka az áttétek megjelenése és jelenlétének igazolása $[6,17]$. A daganatok dopamintermelése is felhívhatja a figyelmet, mivel a rosszindulatú phaeochromocytomák nagyobb hányada termel dopamint [2]. Jelen esetünkben mindkét beteg dopaminszintje normális tartományban volt. Ez a tény, valamint a 
TMEM127 gén mutációja esetén az alacsony malignitási ráta megnyugtató betegeink prognózisa szempontjából.

Jelentős különbség van az extraadrenalis megjelenés, azaz a paraganglioma kialakulását illetően a különböző öröklött phaeochromocytomák esetén. Ez a klinikus számára a kivizsgálási terv kialakításában, a beteg követésében játszhat fontos szerepet. Például a MAX és TMEM127 gén mutációja szinte kizárólag csak adrenalis phaeochromocytomával jár, így a gént hordozó, de még nem beteg páciensek esetében a képalkotó vizsgálatokat elég lehet csak a mellékvesékre fókuszálni $[5,10,15$, 18]. Ezt tesszük az ikerpár gyermekei estében, akiknél elég lehet a vizeletkatecholamin- és szérum-CgA-mérés mellett a mellékvesék CT-vizsgálata. Az EGLNl, az SDHC és SDHAF2 gén mutációja viszont szinte csak paragangliomát eredményez. Az SDHD gén érintettsége 90\%-ban vezet extraadrenalis lokalizációhoz, míg a Ret gén mutációja mindig adrenalis phaeochromocytomát okoz $[4,5]$.

Mindezekből kitünik, hogy gyakran a sporadikusnak tûnő phaeochromocytomákról kiderül, hogy genetikailag determinált, öröklődő betegségről van szó. A pontos genetikai eltérés tisztázása alapvető fontosságú mind a betegség lefolyásának és súlyosságának, mind malignitási hajlamának megítélése szempontjából. Ez viszont hozzásegít a beteg korrekt kezeléséhez, a családtagok szüréséhez, valamint a betegek megfelelő követéséhez.

Anyagi támogatás: A közlemény megírása anyagi támogatásban nem részesült.

Szerzői munkamegosztás: T. G.: Betegek kivizsgálása, adatok gyújtése, irodalomkutatás, a kézirat megszövegezése. P. A.: Genetikai vizsgálatok elvégzése, a kézirat revíziója. T. M.: Betegek kivizsgálása. A cikk végleges változatát mindhárom szerző elolvasta és jóváhagyta.

Érdekeltségek: A szerzőknek nincsenek érdekeltségeik.

\section{Irodalom}

[1] Igaz, P.: Pheochromocytoma. In: Leövey, A., Nagy, V. E., Paragh, Gy., et al. (eds.): Handbook of endocrine and metabolic diseases. [Phaeochromocytoma. In: Leövey, A., Nagy, V. E., Paragh, Gy., et al. (szerk.): Az endokrin és anyagcsere-betegségek gyakorlati kézikönyve.] Medicina Könyvkiadó, Budapest, 2010. [Hungarian]

[2] Berkel, A., Lenders, J. W., Timmers, H. J.: Biochemical diagnosis of phaeochromocytoma and paraganglioma. Eur. J. Endocrinol., 2014, 170(3), R109-R119.
[3] Fishbein, L., Orlowski, R., Cohen, D.: Pheochromocytoma/para ganglioma: Rewiew of perioperative management of blood pressure and update on genetic mutations associated with phaeochromocytoma. J. Clin. Hypertens. (Greenwich), 2013, 15(6), $428-434$.

[4] Welander, J., Söderkvist, P., Gimm, O.: Genetics and clinical characteristics of hereditary pheochromocytomas and paragangliomas. Endocr. Relat. Cancer, 2011, 18(6), R253-R276.

[5] Dabia, P. L.: Pheochromocytoma and paraganglioma pathogenesis: learning from genetic heterogeneity. Nat. Rev Cancer, 2014, 14(2), 108-119.

[6] Mete, O., Tischler, A. S., de Krijger, R., et al.: Protocol for the examination of specimens from patients with pheochromocytomas and extra-adrenal paragangliomas. Arch. Pathol. Lab. Med., 2014, 138(2), 182-188.

[7] Galan, S. R., Kann, P. H.: Genetics and molecular pathogenesis of pheochromocytoma and paraganglioma. Clin. Endocrinol. (Oxf.), 2013, 78(2), 165-175.

[8] Burnichon, N., Lepoutre-Lussey, C., Laffaire, J., et al.: A novel TMEM127 mutation in a patient with familial bilateral pheochromocytoma. Eur. J. Endocrinol., 2011, 164(1), 141-145.

[9] Yao, L., Schiavi, F., Cascon, A., et al.: Spectrum and prevalence of FP/TMEM127 gene mutations in pheochromocytomas and paragangliomas. JAMA, 2010, 304(23), 2611-2619.

[10] Burnichon, N., Cascón, A., Schiavi, F., et al.: MAX mutations cause hereditary and sporadic pheochromocytoma and paraganglioma. Clin. Cancer Res., 2012, 18(10), 2828-2837.

[11] Qin, Y., Yao, L., King, E. E., et al.: Germline mutations in TMEM127 confer susceptibility to pheochromocytoma. Nat. Genet., 2010, 42(3), 229-233.

[12] Foster, K. G., Fingar, D. C.: Mammalian target of rapamycin (mTOR): conducting the cellular signaling symphony. J. Biol. Chem., 2010, 285(19), 14071-14077.

[13] Carracedo, A., Ma, L., Teruya-Feldstein, J.: Inhibition of mTORCl leads to MAPK pathway activation through a PI3Kdependent feedback loop in human cancer. J. Clin. Invest., 2008, 118(9), 3065-3074.

[14] Pópulo, H., Lopes, J. M., Soares, P.: The mTOR signalling pathway in human cancer. Int. J. Mol. Sci., 2012, 13(2), 1886-1918.

[15] Zuber, S. M., Kantorovich, V., Pacak, K.: Hypertension in pheochromocytoma: characteristics and treatment. Endocrinol. Metab. Clin. North Am., 2011, 40(2), 295-311.

[16] Toledo, S. P., Lourenco, D. M. Jr., Sekiya, T., et al.: Penetrance and clinical features of pheochromocytoma in a six-generation family carrying a germline TMEM127 mutation. J. Clin. Endocrinol. Metab., 2015, 100(2), E308-E318.

[17] Korevaar, T. I., Grossman, A. B.: Pheochromocytomas and paragangliomas: assessment of malignant potential. Endocrine, 2011, 40(3), 354-365.

[18] Elston, M. S., Meyer-Rochow, G. Ү., Prosser, D., et al.: Novel mutation in the TMEM127 gene associated with phaeochromocytoma. Intern. Med. J., 2013, 43(4), 449-451.

(Tóth Géza dr., Salgótarján, Füleki út 54-56., 3100 e-mail: gezatothdr@gmail.com) 